\title{
The 2020 Pillar Two Blueprint: What Can the GloBE Income Inclusion Rule Do That CFC Legislation Can't Do?
}

\section{INTRODUCTION}

It was no later than in the policy note of January $2019^{1}$ that the plan to introduce a Global Minimum Tax (GloBE) was first mentioned as Pillar Two of the ongoing search for a comprehensive solution to the tax challenges arising from the digitalization of the economy. ${ }^{2}$ Without much of a debate on the objectives of the GloBE, public consultations were held in February $2019^{3}$ and November $2019^{4}$ in order to collect comments from stakeholders on technical and practical issues of Pillar Two. On 14 October 2020, the OECD published a Blueprint on Pillar Two (Blueprint $)^{5}$ clarifying important design aspects of the GloBE.

In the beginning, the GloBE appeared to be directed against (very) low taxation of corporate profits in general. Now in the Blueprint, a formulaic substance carve-out has been integrated to exclude a fixed return for substantive activities and reduce the scope of the GloBE to excess returns. By excluding routine profits based on a formulaic activity assumption, the GloBE income inclusion rule (IIR) is converging with income inclusion by controlled foreign company (CFC) regimes, known since the early 1960s. It is the farewell to the original idea of a worldwide minimum tax.

The Blueprint makes no secret of the proximity of the GloBE IIR to conventional CFC regimes: 'The operation of the IIR is, in some respects, based on traditional CFC rule principles and triggers an inclusion at the level of the shareholder where the income of a controlled foreign entity is taxed at below the effective minimum tax rate', ${ }^{6}$
It also states that, although similar in operation, the GloBE IIR and CFC rules can co-exist because they have different policy objectives, ${ }^{7}$ albeit without specifying in which way their objectives diverge. The question why a GloBE income inclusion is required in addition to the existing CFC income inclusion is not even asked.

Is a GloBE IIR actually needed alongside the CFC rules as they were recommended in OECD BEPS 2015 Action 3? In order to answer this question, the commonalities of and differences between traditional CFC regimes and the GloBE must first be considered. If the two regimes are juxtaposed, the question of their interaction arises. Since it is unlikely that the GloBE can replace the existing CFC legislation, consolidating the GloBE and CFC rules could be a way to avoid additional compliance burdens. Instead of introducing new instruments that are not coordinated with the existing rules, it would make more sense to refine the existing rules in light of the GloBE debate.

\section{Is THERE A NEED FOR ADDITIONAL INSTRUMENTS ADDRESSING BEPS ISSUES?}

After it turned out that the main focus of the OECD minimum tax proposal is no longer on regulating tax competition in general and not on establishing a lower limit to the race to the bottom of corporate tax rates, the goal of addressing unsolved BEPS challenges is put at the heart of Pillar Two. ${ }^{8}$

\section{Notes}

OECD, Addressing the Tax Challenges of the Digitalisation of the Economy - Policy Note, OECD/G20 Base Erosion and Profit Shifting Project (OECD Publishing Jan. 2019). OECD, Programme of Work to Develop a Consensus Solution to the Tax Challenges Arising from the Digitalisation of the Economy, OECD/G20 Base Erosion and Profit Shifting Project 6, 40 (OECD Publishing May 2019).

OECD, Addressing the Tax Challenges of the Digitalisation of the Economy, Public Consultation Document, Public Consultation Document, 13 Feb. - 6 Mar. 2019 (OECD Publishing Feb. 2019).

OECD, Global Anti-Base Erosion Proposal ('GloBE'), Pillar Two, Public Consultation Document, 8 Nov. 2019 - 2 Dec. 2019 (OECD Publishing Nov. 2019).

OECD, Tax Challenges Arising from Digitalisation - Report on Pillar Two Blueprint: Inclusive Framework on BEPS, OECD/G20 Base Erosion and Profit Shifting Project (OECD Publishing Oct. 2020); accompanied by the Public Consultation Document, Reports on the Pillar One and Pillar Two Blueprints, 12 Oct. - 14 Dec. 2020 (OECD Publishing Oct. 2020).

Pillar Two Blueprint, supra n. 5, para. 9.

Ibid., fn. 1.

8 Ibid., para. 8 reifies that GloBE is about ensuring 'that large internationally operating businesses pay a minimum level of tax regardless of where they are headquartered or the jurisdictions they operate in'. 
Especially BEPS Action 3 on CFC rules contained multiple guidelines for effective protection against profit shifting and long-term deferral of taxation. Thus, it is surprising that, only five years later, further measures are proposed. Where is the need? Which BEPS issues are still unresolved? What are the loopholes not closed by the final reports on Actions 2-15?

The problem starts at the beginning of the BEPS process. At no point was the magnitude of the BEPS problem remotely quantified. Surely, there were very prominent cases of big tech companies $\left(\mathrm{GAFA}^{9}\right)$ paying almost no tax. Maybe this issue has already been solved at large by the US GILTI ${ }^{10}$ legislation? That is not known. Since 2015 , countries followed the OECD recommendation of 2015 and implemented anti-BEPS measures. By now, dozens of countries apply CFC rules. ${ }^{11}$ However, it is still too early to evaluate with sufficient certainty the effects of the 2015 reports. $^{12}$ A comprehensive impact assessment is lacking that would allow us to substantiate the size and quality of remaining BEPS challenges.

\section{The GloBE design after the Blueprint}

\section{I Minimum Taxation in Residence and Source Country}

Although the OECD does not have the answers to these questions, the GloBE concept has gained significant ground over the last year and a half. The primary building blocks are unchanged. In the residence state, the GloBE consists of

(1) Income inclusion rule in relation to subsidiaries

(2) Switch-over rule (change from the exemption to the imputation method) with regard to profits of permanent establishments

In the source state, it consists of

(3) Undertaxed payments rule (UTPR)

(4) Subject-to-tax rule

The shared logic of all of these measures is their supplementary character. They are only actuated if the tax burden is considered otherwise insufficient.

After specific design issues were discussed in the public consultations held in 2019, the Blueprint answers some open questions, the most important of which concern the determination of the low taxation including the question of blending as well as the scope and the question of carve-outs.

\subsection{Determination of the Low Taxation}

The determination of low taxation as the initiating event for the application of the GloBE rules is supposed to occur on a jurisdictional basis. ${ }^{13}$ This allows - different to a per entity approach - blending within a jurisdiction. A very low effective tax rate of one subsidiary due to the applicability of R \& D incentives/patent boxes, for instance, can be compensated with the higher taxation of other subsidiaries in the same jurisdiction. Nevertheless, a jurisdictional approach would - unlike the GILTI or a worldwide blending GloBE approach - not foster foreign-to foreign shifting ${ }^{14}$ but would target single low-tax jurisdictions.

In order to avoid a full redetermination of the tax base of all subsidiaries by the parent entity, the starting point for the determination of a CFCs' effective tax rate is the financial accounting standard ${ }^{15}$ of the parent entity with certain modifications to achieve an approximation to the taxable income.

\subsection{Formulaic Carve-Out}

The more radical innovation in terms of the character of the GloBE concerns the decision for a formulaic substance carve-out based on a payroll and a tangible asset component. Expenses for payroll and tangible assets are assumed to indicate activity in a jurisdiction. The carve-out will be computed on a jurisdictional basis by the situs of the employees and the location of the tangible assets in order to assign the activity to the individual jurisdictions.

Carve-outs can serve different functions:

- There would be an obvious need for a carve-out for preferential tax regimes that result in low taxation but conform to the modified nexus approach if the OECD wanted to avoid inconsistencies with its 2015 work on Action 5.

- Concerns of the effect of the GloBE on reasonable and justified competition strategies of developing countries offering tax holidays, etc. to foreign investors also advocate for carve-outs. ${ }^{16}$

\section{Notes}

Google, Apple, Facebook, Amazon.

10 Global Intangible Low Taxed Income, IRC § 951A.

11 Forty nine Countries have CFC legislation, see OECD, Corporate Tax Statistics 49 (2020), https://www.oecd.org/tax/tax-policy/corporate-tax-statistics-second-edition.pdf (accessed 5 Oct. 2020).

12 A. Christians \& S.E. Shay, General Report, in Assessing BEPS: Origins, Standards, and Responses, IFA Cahiers vol. 102A, 50 (IFA 2017).

13 Pillar Two Blueprint, supra n. 5, paras 248-285.

14 D. N. Shaviro, The New Non-Territorial US International Tax System, Part 2, 160 Tax Notes, 171, 179-185, at 183-184 (24 July 2018).

15 Pillar Two Blueprint, supra n. 5, paras 154-247.

16 P. Pistone et al., The OECD Public Consultation Document 'Global Anti-Base Erosion (GloBE) Proposal - Pillar Two': An Assessment, 74(2) Bull. Int'l Tax'n 62, 64, at 74 (2020) plead for such carve-outs in order to avoid treaty overrides in regard to tax sparing clauses. 
- Finally, substance/activity requirements may be considered necessary in order to facilitate justification in the EU context. ${ }^{17}$

The Blueprint does not refer to any of these reasons. By including a formulaic substance carve-out, the Blueprint intends to limit the scope of the GloBE to 'excess income' that is predominately intangible-related income and identified as most susceptible to BEPS challenges. ${ }^{18}$ The influence of the GILTI is unmistakable even if the technique slightly differs. The GILTI as well is meant to be restricted to foreign low taxed intangible income in a formulaic way, providing a carve-out for tangible assets. ${ }^{19}$ Whether the exclusive application to excess profits turns the minimum tax into an instrument of taxing the digital economy depends on whether and to what extent corporations in traditional industries also generate excess profits and the definition of the excess profit. ${ }^{20}$ It is also far from obvious that low taxed IP income can be equated with tax avoidance or aggressive tax planning. However, applying the GloBE exclusively on excess returns can be advantageous in regard to the competitiveness of resident corporations and could widely preserve capital import neutrality. ${ }^{21}$ If a multinational enterprise (MNE) earns excess returns, it can be assumed that this is due to less competitive local firms in the source country's market and less intense competition in the source country.

This may justify the considerable administrative complexity of the application of the income inclusion only to excess returns. The United States' attempt to simplify the determination of the excess profit based on tangible depreciable assets $(\mathrm{QBA}=$ qualified business assets) used abroad has been criticized in view of its complexity and the risk of incentivizing transfers of QBA abroad. ${ }^{22}$ Nevertheless, the GloBE carve-out also contains a tangible asset component. The additional payroll component, however, may be less prone to manipulation.

\subsection{Instrument for Big MNEs}

Considering its complexity, the application of GloBE is supposed to be limited to MNEs with a consolidated revenue of EUR 750 million or more, ${ }^{23}$ the same threshold used for country-by-country reporting. ${ }^{24}$ This may create the need for a targeted anti-avoidance rule in order to prevent that MNEs will be split in order to go below the threshold.

\subsection{No Word on the Minimum Tax Rate}

The question of the minimum tax rate, which could be regarded as the most important 'detail' of the GloBE, ${ }^{25}$ is not even touched upon in the Blueprint. In fact, this is not a technical question of design but a political one, and one that is highly controversial. Thus, it needs intense negotiations by the 137 members of the Inclusive Framework that seem to be almost impossible under the conditions of the Covid-19 pandemic. On the other hand, many questions of design cannot be separated from the tax rate. For example, the question of how many companies will be affected by the GloBE depends pivotally on the tax rate. If the tax rate is very low, many jurisdictions can be excluded from the outset. It would also be possible to use white or black lists for simplification. A higher minimum tax rate, on the other hand, increases the scope of application, resulting in higher additional compliance costs.

\section{How close does GloBe come to EXISTING CFC LEGISLATION?}

\section{I Open Questions of the Interaction Between GloBE and Existing CFC Legislation}

Activity or substance reservations move the minimum tax almost indistinguishably in the direction of a CFC regime. ${ }^{26}$ Should both instruments coexist, the question arises of the interaction between the two systems. The Blueprint does not deal with the relationship between the two regimes. It neither comments on which cases will be covered by the GloBE IIR in the future that are currently not covered by conventional CFC regimes nor does it

\section{Notes}

17 J. Englisch \& J. Becker, International Effective Minimum Taxation - The Globe Proposal, 11(4) World Tax J. 483, at 524 et seq. (2019); M. P. Devereux et al., The OECD Global Anti-Base Erosion ('GloBE') Proposal, Oxford University Centre for Business Taxation 6, at 53 (Jan. 2020).

18 Pillar Two Blueprint, supra n. 5, para. 18.

19 OECD, Programme of Work, supra n. 2, at 29.

20 See the analysis by M. A. Sullivan, GILTI and That Disappointing Deemed Tangible Return, 159 Tax Notes 773 (7 May 2018).

21 H. Grubert \& R. Altshuler, Fixing The System: An Analysis of Alternative Proposals for the Reform of International Tax, 66(3) Nat'l Tax J. 671, at 673-675 (2013).

22 E. J. Stevens \& H. D. Rosenbloom, GILTI Pleasures, 89 Tax Notes Int'l 615 (12 Feb. 2018); more differentiated D. N. Shaviro, The New Non-Territorial US International Tax System, Part 2, 160 Tax Notes 171, 179-185, at 182 (24 July 2018).

23 Pillar Two Blueprint, supra n. 5, para. 113

24 OECD, Transfer Pricing Documentation and Country-by-Country Reporting, Action 13 - 2015 Final Report, OECD/G20 Base Erosion and Profit Shifting Project (OECD Publishing 2015), para. 52 et seq.

25 Pistone et al., supra n. 14.

26 See Pillar Two Blueprint, supra n. 5, para. 682 et seq., referring to the Commentary on Art. 1 of the OECD Model Tax Convention (para. 81), which is addressing the treaty compatibility of CFC regimes, in order to conclude from this that GloBE is treaty compatible as well. 
examine the effects that result from the different scope of application of the GloBE IIR and the CFC regimes and the different legal consequences. In order to gain a better understanding of a co-existence and interaction of both regimes, a comprehensive examination must occur on commonalities of and differences between a GloBE IIR with substance and activity carve-out and CFC legislation for passive income.

A question not addressed here is whether there is a need for a UTPR on intra-group payments in order to avoid tax driven inversions in addition to GloBE or CFC IIR. The risk of inversions may have been an obstacle for some countries like the United States to tighten their CFC regimes in the past. In this context, the question also arises as to the relationship to existing instruments such as the interest barrier and the transfer pricing regime. Moreover, a UTPR with a wide range of applications ${ }^{27}$ would lead to a significant shift in the allocation of tax rights, which requires careful consideration.

\subsection{The Main Building Blocks and Characteristics of Commonly CFC Legislation}

Although there is no one and only CFC legislation, OECD BEPS 2015 Action 3 as well as Articles 7 and 8 of the EU Anti-Tax avoidance directive (ATAD) can serve as a model. Even before active international coordination, ${ }^{28}$ the sixty-seventh Congress of the International Fiscal Association (2013) has also demonstrated a number of commonalities shared by $\mathrm{CFC}$ regimes ${ }^{29}$ :

CFC regimes are not directed against low taxation of foreign income in general. ${ }^{30}$ Most countries adhere to some type of active/passive income concept. Some CFC regimes attribute only the passive income or income from certain transactions while some attribute all of the income of the CFC if it is mainly passive. Interestingly, Action 3 already mentioned an excess profits approach as a possible, though not yet used at that time, way of defining attributable CFC income. ${ }^{31}$
CFC-regimes commonly work on a per-entity basis. In general, they do not allow blending, neither globally nor on a jurisdictional basis, between different CFCs. The determination of the effective tax rate of the single CFC begins with the calculation of the CFC income. For this determination, most frequently, the normal tax accounting rules of the controlling parent entity are applied. ${ }^{32}$

There is no uniform definition of low taxation. Normally, it is defined in relation to the (nominal) tax rate that applies in the parent entity's jurisdiction. Some countries' CFC rules already come into effect if the CFC's effective tax rate is only slightly lower than the one of the parent entity (e.g. the United States and Germany). Other jurisdictions include the CFC's income in the parent's tax base only if it is taxed at less than half of the parent's tax rate. This is also the minimum standard foreseen in Article 7, paragraph 1 lit. b ATAD. Before, Action 3 recommended the application of $\mathrm{CFC}$ regimes only if the CFCs effective tax rates were 'meaningfully' lower than those applied by the parent jurisdiction. ${ }^{33}$

Some countries work with white, black, and grey lists to identify jurisdictions with acceptable or unacceptable tax levels, a procedure also recommended by Action 3 due to its significant potential for simplification. ${ }^{34}$

When countries apply de minimis thresholds to exclude insignificant units and thereby reduce the administrative burden, these are measured by the respective CFC's profits $^{35}$ and not by the consolidated group revenue.

\subsection{Similarities and Differences}

\subsection{Similar Objectives}

Is it true that the objectives of the GloBE and of CFC regimes differ? This author has doubts as there are significant intersections, particularly in regard to the GloBE IIR.

Despite the ambiguity of the Pillar Two objectives, the Blueprint draws focus to the remaining BEPS issues. 'Ensuring that all internationally operating businesses pay a minimum level of tax' may sound broader, however,

\section{Notes}

27 Pillar Two Blueprint, supra n. 5, para. 495 speaks of 'any deductible payment'.

28 However, the OECD had already prepared the ground for the international spread of CFC with its 1996 Report on Controlled Foreign Company Legislation. See also B. J. Arnold, The Evolution of Controlled Foreign Corporation Rules and Beyond, 73 Bull. Intl. Taxn. 631, at 631 (2019).

29 A. P. Dourado, The Role of CFC Rules in the BEPS Initiative and in the EU, 3 Brit. Tax Rev. 340, at 343 (2015); in detail M. Dahlberg \& B. Wiman, General Report, in The Taxation of Foreign Passive Income for Groups of Companies, Cahiers de droit fiscal international, Vol. 98a (IFA 2013)

30 Only the Brazilian CFC regime attributes CFC income irrespective of its nature (passive/active). See in detail the differences between the Brazilian CFC regime and Action 3 C. Vellasco Lessa, CFC Rules: An Evaluation of Brazilian Legislation and BEPS Action 3, Master Theses (Tilburg University 2017).

31 OECD, Designing Effective Controlled Foreign Company Rules, Action 3-2015 Final Report, OECD/G20 Base Erosion and Profit Shifting Project (OECD Publishing 2015), para. 87.

32 Dahlberg \& Wiman, supra n. 27, at 38; see also Art. 8, para. 1, ATAD

33 OECD, Action 3-2015 Final Report, supra n. 29, para. 51.

34 Ibid., para. 62.

35 See e.g. Art. 7, para. 4, lit. 1, b ATAD: not more than EUR 750000 accounting book profits. Interestingly, here ATAD refers to the financial accounting, while otherwise it is always based on the tax accounting rules. 
the idea of a general minimum tax is not reflected in the design decisions taken by the Blueprint.

CFC regimes also intend to tackle artificial constructions $^{36}$ and book profit shifting. ${ }^{37}$ OECD Action 3 was like the GloBE directed towards enabling countries to counter BEPS situations in a comprehensive manner. ${ }^{38}$ Additionally, CFC rules are designed in a manner to maintain the balance between taxing foreign income and maintaining competitiveness of domestic MNEs. In general, CFC regimes do not pursue an overarching goal of worldwide taxation.

\subsubsection{Comparison of Prerequisites and Legal Consequences}

On closer examination, however, the design of the GloBE deviates considerably both in terms of the prerequisites and the legal consequences from common CFC regimes. This makes it difficult to assess the effects of an application of the GloBE alongside CFC rules. The most significant difference is that the GloBE is limited to large MNEs with a consolidated group revenue of EUR 750 million or more while CFC rules apply without regard to the group's overall revenue.

Understanding the differences in regard of the inclusion amount is even more intricate due to the different systematic of the formulaic GloBE substance carve-out in comparison with the traditional distinction between passive and active income. It is unclear to what extent passive income equals the excess returns determined by the components payroll and tangible assets. Furthermore, traditional CFC regimes determine the CFC's effective tax rate based on tax accounting applying the tax law of the parent entity while the GloBE is supposed to use the financial accounting as a starting point.

Another obvious difference is that common CFC regimes tax the inclusion amount at the unmitigated domestic tax rate. The inclusion of the CFC's income into the parent's profits results in taxation at the domestic level. In contrast, minimum taxes conceptually burden the foreign profit at a lower tax rate than the regular tax rate for domestic profits.

In regard to blending for purposes of the determination of the effective tax burden, the GloBE would accord more with traditional CFC regimes than the GILTI because it will be applied on a jurisdictional instead of on a worldwide basis. The smallest unit to which a minimum tax can be applied is, as in most CFC regimes, the single CFC.
Accordingly, losses and profits of different CFCs cannot be consolidated. In exact contrast to this, the GILTI is designed to aggregate the worldwide income of all CFCs. A jurisdiction specific approach ${ }^{39}$ that is currently proposed for the GloBE can be conceived as a middle course.

\section{GloBE AND CFC SIDE BY SIDE?}

Minimum taxes are commonly discussed as a supplement to existing anti-BEPS rules. The US GILTI taxation is also layered on top of Subpart $\mathrm{F}$ which has priority over the GILTI. This coexistence, however, leads to complex tax planning issues, illustrated by the juxtaposition of Subpart $\mathrm{F}$ and the GILTI. ${ }^{40}$

Compared with the application of CFC rules, the GloBE would have the advantage of the application of the lower minimum tax that would be final. Thus, CFC regimes would need to have priority over the GloBE. Otherwise, big MNEs would have a competitive advantage over domestic groups and over other MNEs that do not reach the threshold of EUR 750 million.

Thus, initially, any entity with CFCs would need to determine the inclusion amount under CFC legislation. The attributed CFC income would no longer qualify for inclusion under the GloBE IIR because it would no longer be low taxed. The GloBE would only apply if and insofar as the excess returns determined by the formulaic substance carve-out would exceed the attributed passive CFC income. Differences could also occur due to different low tax definitions.

Without going into detail, it is obvious that, due to the need to apply two different sets of IIR, - the small number of - MNEs subject to the GloBE would face extra compliance burdens that would not necessarily lead to any further taxation.

\section{GloBE instead OF CFC RULes?}

Considering the kinship of the GloBE and CFCs, is there any chance that countries adopting the GloBE will abolish their CFC regimes? The answer is clear: No! This is at least true for high tax countries, and it is also not intended by the OECD which assumes that both systems will co-exist as they allegedly serve different policy objectives $^{41}$

\section{Notes}

36 See Explanatory Memorandum of ATAD, No. 12

37 OECD, Action 3-2015 Final Report, supra n. 30, paras 1, 6 et seq.

38 In depth Dourado, supra n. 28, at 340.

39 Pillar Two Blueprint, supra n. 5, para. 9; and before Pistone et al., supra n. 13, at 25 (para. 96). Favoured also by Englisch \& Becker, supra n. 15, 501.

40 See M. Herzfeld, Did Treasury Weaken the TCJA?, 166 Tax Notes Federal 205, at 208 (13 Jan. 2020); E. Shay, A GILTI High-Tax Exclusion Election Would Erode the US Tax Base, Tax Notes Federal 1129 (18 Nov. 2019); D. Rosenbloom \& J. Lee, CFCs ad the Individual Shareholder, Tax Notes International 1429 (14 Sept. 2020 ).

41 Pillar Two Blueprint, supra n. 5 , para. 9 fn. 1 
The GloBE IIR is less effective than most CFC regimes, ${ }^{42}$ especially if the minimum tax rate, as the Inclusive Framework is content to agree, is rather low. From the perspective of an MNE in a high tax country, it is still attractive to shift income in order to enjoy a $10 \%$ or $12.5 \%$ effective tax rate instead of a $25 \%, 30 \%$, or even higher one. Furthermore, the passive CFC income is commonly fully included in the parent's tax base thus the application of CFC regimes results in taxation at the normal domestic tax rate. Consequently, it is improbable that countries, such as Germany or the United States applying high 'low taxation' thresholds only slightly below the domestic tax level, ${ }^{43}$ would be willing to replace existing CFC regimes with the GloBE.

Another interesting question is whether EU Member States bound by the ATAD would be allowed to replace their CFC regimes with a GLoBE, which is similar but not the same. In view of the proposed simplifications, ${ }^{44}$ European low tax countries could be interested in introducing the GloBE IIR as a substitute for the existing CFC IIR. For them, there would be practically no difference whether they apply the minimum tax rate or their equally low domestic tax rate on the inclusion amount. However, not only the big MNE group threshold but also the GloBE determination of the inclusion amount would not be covered by Article 7 paragraph 2 ATAD even if the amount would not deviate significantly.

\section{INTEGRATION OF GIoBE INTO EXISTING CFC REGIMES}

Therefore, it is more sensible to think about the opposite way and integrate the GloBE into the existing CFC regimes.

Different to the Action 3 recommendations for effective CFC regimes, which contained quite a few different options, the Blueprint narrows the various options for the design of a minimum tax down to one model aiming at strict rule coordination by model legislation. ${ }^{45}$ However, most of the elements of the GloBE IIR are covered by the Action 3 recommendations. Thus, the GloBE IIR can be understood as an advancement of the 2015 recommendations on the CFC IIR. This allows copying GloBE elements into the existing CFC regimes. Probably that would not even lead to an extension of CFC taxation but could achieve greater conformity of CFC regimes and could potentially even be used for their simplification.

It is not likely that the application of CFC regimes will be limited to big MNEs with a consolidated return of EUR 750 million or more. In the context of country-by-country reporting, it has been explained that, with this threshold, approximately $85 \%$ to $90 \%$ of MNEs are excluded but that the country-by-country report will nevertheless be filed by MNEs controlling approximately $90 \%$ of corporate revenues. ${ }^{46}$ To this author's knowledge, there is no data on the size of those groups that are currently subject to CFC legislation. However, if this threshold would apply in general, CFC regimes would lose their deterrent effect and would provide an incentive for smaller groups to make use of BEPS arrangements without risk.

It is equally unlikely that countries will be willing to replace taxing the inclusion amount at the level of their normal domestic tax rate with the application of the much lower minimum tax rate. ${ }^{47}$ Thus, the question has to be turned around. What would happen if the excess profits attributed under the GloBE were taxed back at the respective domestic tax level of the ultimate parent entity? Englisch \& Becker ${ }^{48}$ contend that limiting the tax burden on the inclusion amount to a low minimum tax rate is necessary in order to not risk the MNEs' subsidiaries' competitiveness. However, this concern was mainly relevant if the GloBE applied on all foreign income of the MNE and also on income from an active conduit of business. When limited to excess returns, this argument loses relevance because foreign parented companies with excess returns have competitive advantages over domestic competitors.

Whether other components of the GloBE, especially jurisdictional blending and the excess return approach, should be made the standard in CFC regimes depends on an analysis of their effects as well as on their potential for simplification. The limitation to specific categories of income is one of the biggest weaknesses of classic CFC regimes, making them both costintense in terms of compliance and prone to circumvention. A formulaic carve-out may be preferable, though this is not that obvious because the GloBE carve-out relies on fungible criteria like payroll and tangible assets. Just as with any formulary apportionment system, this entails the risk of factor shifting in

\section{Notes}

42 J. C. Fleming Jr., R. J. Peroni \& S. E. Shay, Incorporating a Minimum Tax in a Territorial System, 157 Tax Notes 73,75, at 76 (2 Oct. 2017), call the minimum tax an 'imperfect base protection measure', and argue therefore for additional CFC regimes applied to passive mobile income.

43 However, normally, the low taxation threshold is significantly below the domestic tax rate. The EU Anti-Tax Avoidance Directive foresees $50 \%$ of the statutory domestic tax rate, which is, however, only a minimum standard, allowing higher thresholds. Quite common is 75\%; see Dahlberg \& Wiman, supra n. 27, at 36-38.

44 See Pillar Two Blueprint, supra n. 5, paras 376-409.

45 Pillar Two Blueprint, supra n. 5, para. 22. Though in regard of US GILTI the Blueprint make quite a bit effort to declare compatibility with a future GloBE IIR, see Pillar Two Blueprint, supra n. 5, paras 25-28.

46 OECD, Action 13-2015 Final Report, supra n. 22, para. 52.

47 Interestingly OECD, Action 3-2015 Final Report, supra n. 29, para. 119, discusses the alternative of a top-up tax below the domestic statutory corporate tax rate. It is a possible option, however, from the perspective of a higher-tax jurisdiction in effectively eliminating incentives to shift profits (para. 120).

48 Englisch \& Becker, supra n. 15, at 2.2.7. 
order to reduce the inclusion amount which then needs to be prevented by complex targeted anti-avoidance rules. ${ }^{49}$

Using financial group accounting for calculating the CFC's effective tax rate (ETR) instead of recalculating the CFC's tax base by application of the parent entity's tax accounting rules could be a significant simplification depending on the number of corrections needed to adjust to a (standardized) tax base.

Another question is whether integrating the GloBE into existing CFC regimes would require a uniform low taxation threshold equivalent to a uniform minimum tax rate. The lower that the GloBE minimum tax rate would be set, the more likely CFC regimes of high tax countries would apply a higher threshold, as is the case in the United States with the effective GILTI tax rate of $13.125 \%$ while the Subpart F inclusion takes effect for all income taxed below the high-tax exception of $18.9 \%$. In other countries with a low statutory tax rate, the domestic tax rate might even be below the GloBE minimum tax rate. However, it does not need a uniform definition of low taxation as a triggering moment. If all states comply with a uniformly defined lower limit, it will not be harmful if high-tax jurisdictions also include higher taxed foreign profits in the parent's tax base. Low-tax countries currently applying tax rates below the potential GloBE tax rate need to raise their domestic tax rate in any case because, otherwise, MNEs would be disadvantaged to purely domestic groups which would be not acceptable, at least under European Law.

\section{Conclusion}

During the entire BEPS process, the OECD has shown only very little interest in simplifying the international tax system. National legislators are also not willing to reduce complexity; instead, they are cautious to not create new loopholes. In this respect, the chance that the Pillar Two debate will lead to a reduction of complexity is minimal. It is more likely that the future system will consist of three layers of base protection:

- Targeted base protection by the special anti-avoidance rules adopted in the aftermath of BEPS 1.0.

- An only slightly more comprehensive GloBE as the result of BEPS 2.0

- Additional application of general anti-avoidance rules on a case-by-case basis

All of this will not stop international tax planning nor international tax competition. Thus, it is all the more important to understand and to admit that a GloBE IIR with a substance carve-out is nothing else than an advanced CFC rule. This could ease the implementation of an overhaul of Action 3 instead of ending up with a system of two different $\mathrm{CFC}$ regimes.

Johanna Hey

Director of the Institute for Tax Law at the University of Cologne, Germany. Email: Johanna.Hey@uni-koeln.de.

\section{Notes}

49 For example, Pillar Two Blueprint, supra n. 5, para. 345. 